\title{
PERTANGGUNG JAWABAN PIDANA TERHADAP PELAKU PENGGELAPAN DENGAN MENGGUNAKAN JABATAN MENURUT PASAL 374 KUHP DALAM PENDEKATAN TEORI PEMIDANAAN (Analisis Putusan Pengadilan Negeri Jakarta Selatan Nomor 1316/Pid.B/2017/PN.Jkt.Sel)
}

\author{
${ }^{1}$ Miftakul Muntaha, ${ }^{2}$ Kartono \\ Fakultas Hukum Universitas Pamulang \\ E-mail:1mmuntaha233@gmail.com,2dosen01490@unpam.ac.id
}

Received: Juni 2020/Revised: Juli 2020/Accepted: Agustus 2020

\begin{abstract}
ABSTRAK
Kejahatan yang marak dan terus berkembang hingga saat ini adalah kejahatan terhadap harta benda. Salah satu kejahatan yang merupakan kejahatan terhadap harta benda adalah tindak pidana penggelapan. Tindak pidana penggelapan diatur dalam buku II Kitab Undang-undang Hukum Pidana pada Pasal 372 - 377 KUHP yang merupakan kejahatan yang sering terjadi di berbagai lapisan bawah sampai lapisan masyarakat atas, penyalahgunaan kepercayaan adalah salah satu factor yang mendominasi sebagai unsur utama terjadinya tindak pidana ini. Penggelapan memiliki jenis yang berbeda-beda salah satunya Penggelapan dengan jabatan merupakan penyakit masyarakat yang berkaitan erat dengan kejahatan, yang dalam proses sejarahnya dari generasi ke generasi ternyata kejahatan tersebut merupakan kejahatan yang merugikan orang lain dan atau instansi tempat pelaku bekerja. Tindak pemidanaan terhadap tindak pidana penggelapan dengan jabatan haruslah berbeda dengan tindak pidana penggelapan biasa karena terdapat unsur memberatkan didalamnya sebagaimana telah diatur dalam KUHP. Pertimbangan hakim dan fakta hukum merupakan bagian yang berpengaruh dalam menentukan penjatuhan sanksi dalam pemidanaan.
\end{abstract}

Kata Kunci : Pertanggungjawaban Tindak Pidana Penggelapan

\section{ABSTRACT}

The crime that is rife and continues to grow until now is a crime against property. One crime that is a crime against property is a crime of embezzlement. Crimes of embezzlement are regulated in book II of the Criminal Law Act in Articles 372 - 377 KUHP which is a crime that often occurs in various layers of the lower layers of society, abuse of trust that 
dominates as the main element of this crime. Embezzlement has different types, one of which is embezzlement by occupation is a community disease that is closely related to crime, which in its historical process from generation to generation turns out that the crime is a crime that harms others and or the agency where the offender works. Criminal acts against embezzlement by position must be different from ordinary embezzlement because there are incriminating elements in it as regulated in the Criminal Code. Judges' considerations and legal facts are an influential part in determining the sanction imposed in criminal proceedings.

Keywords: Liability for Misleading Crimes

\section{PENDAHULUAN}

Kejahatan (tindak pidana) adalah gejala social yang senantiasa dihadapi untuk setiap masyarakat di dunia. Adapun usaha untuk menghapuskannya tidak tuntas karena kejahatan itu memang tidak dapat dihapus. Hal itu terutama disebabkan karena tidak semua kebutuhan dasar manusia dapat dipenuhi secara sempurn lagi pula manusia mempunyai kepentingan yang berbeda-beda yang bahkan dapat berwujud sebagai pertentangan yang prinsipil. Kejahatan yang marak dan terus berkembangan hingga saat ini adalah kejahatan terhadap harta benda. Kejahatan terhadap harta benda adalah berupa penyerangan terhadap kepentingan hukum orang atas benda milik orang lain (bukan milik petindak) salah satunya yaitu tindak pidana penggelapan.

Penggelapan yaitu barang siapa secara tidak sah memiliki barang yang seluruhnya atau sebagian adalah milik orang lain dan yang ada padanya bukan karena kejahatan, ia pun telah bersalah melakukan tindak pidana, misalnya Pasal 372 KUHP yang dikualifikasikan sebagai verduistering atau penggelapan. (C.S.T Kansil, 2000)

Agar seseorang dapat dinyatakan sebagai terdakwa karena telah memenuhi unsur kesengajaan seperti yang disyaratkan dalam rumusan Pasal 372 KUHP, maka disidang pengadilan yang memeriksa perkara terdakwa harus dapat membuktikan bahwa pelaku memang benarbenar:

1. Menghendaki atau bermaksud untuk menguasai suatu benda secara melawan hukum, suatu perbuatan yang bertentangan dengan kewajiban hukumnya atau bertentangan dengan hak orang lain.

2. Mengetahui bahwa yang ia kuasai adalah sebuah benda. 
3. Mengetahui bahwa sebagian atau seluruh benda yang ingin dikuasainya adalah milik orang lain.

4. Mengetahui bahwa benda tersebut ada padanya bukan karena kejahatan. (Lamintang, 2013)

Jenis-jenis Tindak Pidana Penggelapan berdasarkan Bab XXIV (buku II) KUHP pasal 372 sampai dengan 377.

1. Penggelapan Biasa: Yang dinamakan penggelapan biasa adalah penggelapan yang diatur dalam Pasal 372 KUHP: "Barang siapa dengan sengaja dan melawan hukum mengaku sebagai milik sendiri (zich toeegenen) barang sesuatu yang seluruhnya atau sebagian adalah kepunyaan orang lain, tetapi yang ada dalam kekuasaanya bukan karena kejahatan, diancam karena penggelapan dengan pidana penjara paling lama empat tahun,

2. Penggelapan Ringan : Penggelapan Ringan adalah penggelapan yang diatur dalam Pasal 373 dimana yang digelapkan itu bukan hewan dan harganya tidak lebih dari 250,-

3. Penggelapan dengan pemberatan: Penggelapan dengan pemberatan yakni penggelapan yang dilakukan oleh orang yang memegang barang itu berhubungan dengan pekerjaanya atau jabatanya atau karena ia mendapat upah (Pasal 374 KUHP),

4. Penggelapan dengan kalangan keluarga : Penggelapan dengan linkungan keluarga yaitu penggelapan yang dilakukan oleh orangorang yang karena terpaksa disuruh menyimpan barang itu, atau wali, curator, pengurus, orang yang menjalankan wasiat atau pengurus balai derma, tentang suatu barang yang ada dalam tanganya karena jabatanya tersebut (Pasal 375 KUHP).

Memiliki jabatan sebagai Corporate License Muhamad Zaki mantan karyawan, bertugas mengurus perijinan batching plan, seperti IMB, Ijin Domisili, UUG, TDUP, Ijin Lingkungan, Ijin Alat-alat berat di wilayah Jabodetabek dan Jawa Barat di perusahan PT. Holcim Indonesia dengan sengaja melakukan penggelapan dana perusahaan yang berada dalam penguasaannya dengan mempergunakan untuk keperluan pribadinya tanpa seizin dan sepengetahuan dari pihak perusahaan tempat ia bekerja adalah salah satu kasus yang pernah terjadi dan telah diputus oleh Pengadilan Negeri Jakarta Selatan.

Dari kasus diatas dapat diketahui tindak pidana penggelapan dilakukan oleh siapapun terhadap siapapun, termasuk juga pihak yang berada di dalam ataupun diluar lingkungan perusahaan, namun pada umumnya dilakukan oleh pihak yang berada didalam lingkungan 
perusahaan karena biasanya pihak tersebut memahami mengenai pengadilan internal yang berada didalam perusahaan tempat ia bekerja sehingga bukanlah hal yang sulit untuk melakukan penggelapan.

\section{PERMASALAHAN}

Berdasarkan latar belakang masalah yang diuraikan tersebut, pokok permasalahan dalam tulisan ini adalah pertama, Bagaimana hakim dalam mengkualifikasi unsur-unsur tindak pidana penggelapan dengan jabatan sebagaimana pada putusan Nomor 1316/Pid.B/2016/Pn.Jkt.Sel sudah sesuai dengan pasal 374 KUHP? Kedua, Bagaimana sanksi pidana terhadap pelaku dalam Putusan Nomor 1316/Pid.B/2017/PN.Jkt.Sel sudah sesuai dengan teori pemidanaan?

\section{METODE PENELITIAN}

Dalam penulisan ini penulis menggunakan metode penelitian hukum yuridis Normatif yaitu jenis pendekatan dengan menggunakan ketentuan perundang-undangan yang berlaku pada suatu Negara atau metode pendekatan hukum doktrinal yaitu teori-teori hukum dan pendapat para ilmuwan hukum terutama yang berkaitan dengan permasalahan yang dibahas. (Soemitro, 1998)

Pendekatan masalah tersebut kemudian akan dipertajam dengan suatu pendekatan konseptual (Conseptual Approach), yaitu pendekatan yang dilakukan dengan menggunakan konsep-konsep yang dipahami dari pemikiran para ahli atau pakar dalam bidang yang berkaitan dengan permasalahan yang dibahas. (Soemitro, 1998)

\section{PEMBAHASAN}

Tindak pidana merupakan pengertian dasar dalam hukum pidana tindak pidana merupakan pengertian yuridis yang berbeda dengan pengertian kejahatan yang dapat diartikan secara yuridis dan kriminologis. Para ahli hukum pidana sering menggunakan istilah "strafbaar feit" untuk menyebut tindak pidana. Sedangkan di KUHP tidak memberikan penjelasan mengenai perkataan "strafbaar feit" tersebut.

Perkataan "feit" dalam bahasa belanda diartikan sebagian dari kenyataan, sedangkan "strafbaar" beararti dapat dihukum, sehingga secara harfiah perkataan "strafbaar feit' berarti sebagaian dari kenyataan yang dapat di hukum yang sudah barang tentu tidak tepat, oleh karena kelak akan kita ketahui bahwa yang dapat dihukum adalah 
manusia sebagai pribadi dan bukan kenyataan, perbuatan, atau tindakan. (Lamintang P. , 1997)

Menurut Moeljatno, perbutan pidana adalah perbutan yang dilarang oleh suatu aturan hukum, larangan yang mana disertai (sanksi) yang berupa pidana tertentu bagi barang siapa yang melanggar aturan tersebut. Dapat juga dikatakan bahwa perbuatan pidana adalah perbuatan yang oleh suatu aturan hukum dilarang dan diancam pidana asal saja dalam pidana itu diingat bahwa larangan ditunjukan pada perbuatan yaitu "suatu keadaan atau kejadian yang ditimbulkan oleh kelakuan orang, sedangkan ancaman pidananya ditunjukan kepada orang yang menimbulkan kejadian itu".

Perbuatan pidana menurut sistem KUHP kita terbagi atas kejahatan dan pelanggaran, pembagian dalam dua jenis ini, tidak ditentukan dengan dengan nyata-nyata dalam suatu pasal KUHP, tetapi sudah dianggap demikian adanya. Menurut M..v.T pembagian atas dua jenis tadi didasarkan atas perbedaaan prinsipil. Dikatakan bahwa kejahatan adalah rechtdelicten, yaitu perbuatan-perbuatan yang meskipun tidak ditentukan dalam undang-undang, sebagai perbuatan yang bertentangan dengan tata hukum. (Moeljanto, 2008)

Dalam ilmu hukum pidana, unsur-unsur tindak pidana itu dibedakan dalam dua macam yaitu unsur objektif dan subjektif. Unsur objektif menurut P.A.F Lamintang mengemukan bahwa "unsur yang terdapat diluar sisi si pelaku tindak pidana, jadi unsur objektif itu adalah unsur yang ada hubungannya dengan keadaan-keadaan mana tindakan-tindakan dari si pelaku itu harus dilakukan. (Lamintang P. , 1984) Sedangkan Unsur subjektif adalah unsur yang berasal dari dalam diri pelaku, asas hukum pidana menyatakan " tidak ada hukuman kalau tidak ada kesalahan yang diakibatkan oleh kesengajaan dan kealpaan. Pada umumnya para pakar telah menyetujui bahwa kesengajaan terdiri atas 3 bentuk, yakni: (Marpaung, 2005)

1. Kesengajaan sebagai di maksud

2. Kesengajaan dengan keinsafan pasti

3. Kesengajaan dengan keinsafan akan kemungkinan

Pertanggungjawaban adalah suatu perbuatan yang tercela oleh masyarakat dan itu dipertanggungjawabkan pada si pembuatnya. Untuk adanya pertanggungjawaban pidana harus jelas terlebih dahulu siapa yang dapat dipertanggungjawabkan, ini berarti harus dipastikan terlebih dahulu yang dinyatakan sebagai pembuat suatu tindak pidana. (Saleh, 1990) 
Roeslan Saleh mengatakan bahwa: Pertanggungjawaban pidana adalah sesuatu yang dipertanggung jawabkan secara pidana terhadap seseorang yang melakukan perbuatan pidana atau tindak pidana. (Saleh, 1990) Pelaku tindak pidana dapat dipidana apabila memenuhi syarat bahwa tindak pidana yang dilakukannya memenuhi unsurunsur yang telah ditentukan dalam Undang-Undang. Dilihat dari sudut terjadinya tindakan yang dilarang, seseorang akan dipertanggungjawabkan atas tindakan-tindakan tersebut, apabila tindakan tersebut melawan hukum serta tidak ada alasan pembenar atau peniadaan sifat melawan hukum untuk pidana yang dilakukannya. Dan dilihat dari sudut kemampuan bertanggung jawab maka hanya seseorang yang mampu bertanggung jawab yang dapat dipertanggungjawabkan atas perbuatanya. Dalam hal dipidananya seseorang yang melakukan perbuatan seperti melawan hukum tergantung dari apakah dalam melakukan perbuatan ia mempunyai kesalahan dan apabila orang yang melakukan perbuatan itu memang melawan hukum, maka ia akan dipidana.

Berdasarkan hal tersebut, Andi Hamzah menjelaskan bahwa pembuat (dader) harus ada unsur kesalahan dan bersalah yang harus memenuhi unsur, yaitu:

1. Kemampuan bertanggung jawab atau dapatnya dipertanggung jawabkan dari si pembuat.

2. Adanya kaitan psikis antara pembuat dan perbuatan, yaitu adanya sengaja atau kesalahan dalam arti sempit (culpa). Pelaku mempunyai kesadaran yang mana pelaku seharusnya dapat mengetahui akan adanya akibat yang ditimbulkan dari perbuatannya.

3. Tidak adanya dasar peniadaan pidana yang menghapus dapatnya dipertanggungjawabkan sesuatu perbuatan kepada pembuat. (Hamzah, 1997)

Suatu perbuatan dikatakan telah melanggar hukum, dan dapat dikenakan sanksi pidana maka harus dipenuhi 2 (dua) unsur yakni adanya unsur perbuatan pidana (actrus reus) dan keadaan sifat batin pembuat (mens rea). Kesalahan (schuld) merupakan unsur pembuat delik, jadi termasuk unsur pertanggungjawaban pidana yang mana terkandung makna dapat dicelanya si pembuat atas perbuatannya.

Andi Zainal menyatakan bahwa: Dalam hal kesalahan tidak terbukti, berarti bahwa perbuatan pidana (actus reus) sebenarnya tidak terbukti, karena tidak mungkin hakim akan membuktikan adanya kesalahan jika ia telah mengetahui lebih dahulu bahwa perbuatan 
pidana tidak ada atau tidak terbukti diwujudkan oleh terdakwa. (Abidin, 1987)

Berdasarkan uraian di atas maka dapat dinyatakan bahwa pertanggungjawaban pidana mengandung makna bahwa setiap orang yang melakukan tindak pidana atau melawan hukum, sebagaimana dirumuskan dalam undang-undang, maka orang tersebut patut mempertanggung jawabkan perbuatan sesuai dengan kesalahannya. Dengan kata lain orang yang melakukan perbuatan pidana akan mempertanggungjawabkan perbuatan tersebut dengan pidana apabila ia mempunyai kesalahan, seseorang mempunyai kesalahan apabila pada waktu melakukan perbuatan dilihat dari segi masyarakat menunjukan pandangan normatif mengenai kesalahan yang telah dilakukan orang tersebut.

Dalam Kamus Besar Bahasa Indonesia "Penggelapan diartikan sebagai proses, cara dan perbuatan menggelapkan (penyelewengan) yang menggunakan barang secara tidak sah. Dapat diuraikan selanjutnya bahwa penggelapan dapat dikatakan perbuatan merusak kepercayaan orang lain dengan mengingkari janji tanpa perilaku yang baik. Dalam KUHP, Penggelapan dimuat dalam Buku II Bab XXIV yang oleh Van Haeringen mengartikan Istilah Penggelapan ini sebagai "geheel donkermaken" atau sebagai "uitstraling van lichtbeletten" yang artinya "membuat segalanya menjadi gelap" atau "menghalangi memancarnya sinar". Sedangkan Lamintang dan Djisman Samosir mengatakan akan lebih tepat jika istilah Penggelapan diartikan sebagai "penyalah gunaan hak" atau "penyalah gunaan kekuasaan". Akan tetapi para sarjana ahli hukum lebih banyak menggunakan kata "Penggelapan".

Lamintang mengemukakan penjelasannya mengenai tindak pidana penggelapan yaitu: Tindak pidana sebagimana tersebut dalam Bab XXIV KUHP lebih tepat disebut sebagai "tindak pidana penyalahgunaan hak" atau "penyalahgunaan kepercayaan". Sebab inti dari tindak pidana tersebut adalah penyalahgunaan hak atau penyalahgunaan kepercayaan. Karena dengan penyebutan tersebut maka akan memudahkan bagi setiap orang untuk mengetahui perbuatan apa yang sebenarnya dilarang dan diancam pidana dalam ketentuan tersebut. (Tongat, 2006)

Selanjutnya, Tongat menegaskan perihal telaah pengertian tentang penggelapan ini bahwa: Apabila suatu benda berada dalam kekuasaan orang bukan karena tindak pidana, tetapi karena suatu perbuatan yang sah, misalnya karena penyimpanan, perjanjian 
penitipan barang, dan sebagainya. Kemudian orang yang diberi kepercayaan untuk menyimpan dan sebagainya itu mengusai barang tersebut untuk diri sendiri secara melawan hukum, maka orang tersebut berarti melakukan penggelapan. (Tongat, 2006)

M. Sudrajat memberikan pengertian tindak pidana penggelapan yaitu: Penggelapan adalah digelapkannya suatu barang yang harus dibawah kekuasaan si pelaku, dengan cara lain dari pada dengan melakukan kejahatan. Jadi barang itu oleh yang punya dipercayakan kepada si pelaku. Pada pokoknya pelaku tidak memenuhi kepercayaan yang dilimpahkan atau dapat dianggap dilimpahkan kepadanya oleh yang berhak atas suatu barang. (BAssar, 1984)

Adami Chazawi mengemukakan penjelasannya mengenai tindak pidana penggelapan berdasarkan Pasal 372 KUHP yaitu: Perkataan verduistering yang kedalam bahasa kita diterjemahkan secara harfiah dengan penggelapan itu, bagi masyarakat Belanda diberikan secara arti luas (figurlikj), bukan diartikan seperti arti kata yang sebenarnya sebagai membikin sesuatu menjadi tidak terang atau gelap. Lebih mendekati pengertian bahwa petindak menyalahgunakan haknya sebagai yang menguasai suatu benda (memiliki), hak mana tidak boleh melampaui dari haknya sebagai seorang yang diberi kepercayaan untuk menguasai benda tersebut bukan karena kejahatan.

Beberapa pengertian dan penjelasan mengenai arti kata penggelapan dapat kita lihat pula C.S.T. Kansil dan Christine S. T Kansil mendefinisikan penggelapan secara lengkap yaitu: Penggelapan yaitu barang siapa secara tidak sah memiliki barang yang seluruhnya atau sebagian adalah milik orang lain dan yang ada padanya bukan karena kejahatan, ia pun telah bersalah melakukan tindak pidana, misalnya Pasal 372 KUHP yang dikualifikasikan sebagai verduistering atau penggelapan. (C.S.T Kansil, 2000)

Jadi dapat diartikan bahwa penggelapan adalah suatu perbuatan menyimpang yang menyalahgunakan kepercayaan orang lain yang diberikan padanya dan awal barang itu berada ditangannya bukan karena dari hasil kejahatan.

Tindak pidana penggelapan dalam bentuk pokok diatur dalam Pasal 372 KUHP mempunyai unsur-unsur sebagai berikut:

1. Unsur Subjektif

a. Barang Siapa

Kata barang siapa ini menunjukkan kepada orang, yang apabila orang tersebut memenuhi semua unsur tindak pidana 
yang terdapat di dalam tindak pidana tersebut, maka ia disebut sebagai pelaku dari tindak pidana yang bersangkutan.

b. Dengan Sengaja

Dengan sengaja atau opzettelijk. Unsur ini merupakan unsur yang melekat pada subjek tindak pidana, maupun yang melekat pada pribadi pelakunya. Karena merupakan unsur dari tindak pidana penggelapan, dengan sendirinya unsur tersebut harus didakwakan oleh jaksa didalam surat dakwaannya dan karena unsur tersebut didakwakan terhadap terdakwa, dengan sendirinya juga harus dibuktikan disidang pengadilan yang memeriksa perkara terdakwa. (Lamintang P. L., 2013)

Agar seseorang dapat dinyatakan sebagai terdakwa karena telah memenuhi unsur kesengajaan seperti yang disyaratkan dalam rumusan Pasal 372 KUHP, maka disidang pengadilan yang memeriksa perkara terdakwa harus dapat membuktikan bahwa pelaku memang benar-benar:

1) Menghendaki atau bermaksud untuk menguasai suatu benda secara melawan hukum, suatu perbuatan yang bertentangan dengan kewajiban hukumnya atau bertentangan dengan hak orang lain.

2) Mengetahui bahwa yang ia kuasai adalah sebuah benda.

3) Mengetahui bahwa sebagian atau seluruh benda yang ingin dikuasainya adalah milik orang lain.

4) Mengetahui bahwa benda tersebut ada padanya bukan karena kejahatan. (Lamintang P. L., 2013)

Kesengajaan yang ditunjukkan pada semua unsur yang ada dibelakangnya itu harus dibuktikan dalam persidangan. Oleh karenanya hubungan antara orang yang menguasai dengan barang yang dikuasai harus sedemikian langsungnya, sehingga untuk melakukan sesuatu terhadap barang tersebut orang tidak memerlukan tindakan lain.

Jika kehendak dan pengetahuan-pengetahuan terdakwa seperti yang dimaksud diatas dibuktikan, maka orang tersebut dapat dikatakan bahwa terdakwa memenuhi unsur dengan sengaja yang terdapat dalam rumusan Pasal 372 KUHP. Akan tetapi bila tidak dapat dibuktikan salah satu dari kehendak dan pengetahuan-pengetahuan terdakwa tersebut, maka hakim akan memberikan putusan bebas.

c. Melawan Hukum (wederrechtelijk) 
Suatu benda milik orang lain berada dalam kekuasaan seseorang dapat oleh sebab perbuatan melawan hukum (suatu kejahatan) maupun oleh sebab perbuatan yang sesuai dengan hukum. Adami Chazawi menjelaskan bahwa sebagai syarat dari penggelapan ini adalah barang yang berada dalam kekuasaan petindak haruslah oleh sebab perbuatan yang sesuai dengan hukum seperti karena penitipan, pinjaman, perjanjian sewa, penggadaian dan sebagainya.

Pada dasarnya melawan hukum adalah sifat tercelanya atau terlarangnya dari suatu perbuatan tertentu. Didalam doktrin dikenal ada dua macam melawan hukum, yaitu melawan hukum formil dan melawan hukum materil. Melawan hukum formil adalah bertentangan dengan hukum tertulis sedangkan melawan hukum materil ialah perbuatan itu bertentangan dengan asas-asas hukum didalam mayarakat, baik tertulis maupun tidak tertulis. Dalam hubungannya dengan kesengajaan, penting untuk diketahui bahwa kesengajaan pelaku juga harus ditunjukkan pada unsur melawan hukum ini

\section{Unsur Objektif}

Adami Chazawi menerangkan bahwa: Perbuatan memiliki adalah berupa perbuatan menguasai suatu benda seolah-olah ia pemilik benda itu. Dengan pengertian ini dapat diterangkan demikian, bahwa pelaku dengan melakukan perbuatan memiliki atas suatu benda yang berada dalam kekuasaannya adalah ia melakukan perbuatan sebagaimana pemilik melakukan perbuatan terhadap benda itu. Oleh karena sebagai unsur tindak pidana penggelapan, unsur ini mempunyai kedudukan yang berbeda dengan unsur yang sama dalam tindak pidana pencurian sekalipun dengan pengertian yang sama.

Tongat juga mengemukakan pendapat mengenai unsur mengaku sebagai milik sendiri (mengusai) yaitu: Dalam tindak pidana "pencurian" unsur "menguasai" ini merupakan unsur subjektif tetapi dalam tindak pidana penggelapan unsur tersebut merupakan unsur objektif. Dalam hal tindak pidana pencurian, menguasai merupakan tujuan dari tindak pidana pencurian. Dalam hal ini unsur tersebut tidak perlu terlaksana pada saat perbuatan yang dilarang (yaitu mengambil barang itu) selesai. Dalam hal itu hanya harus dibuktikan bahwa pelaku mempunyai maksud untuk menguasai barang itu untuk dirinya sendiri, tanpa perlu terbukti 
barang itu benarbenar menjadi miliknya. Sementara dalam tindak pidana penggelapan, perbuatan menguasai tersebut merupakan perbuatan yang dilarang. Karena perbuatan tersebut merupakan perbuatan yang dilarang, maka tidak ada penggelapan apabila perbuatan menguasai tersebut belum selesai (Tongat, 2006)

Dengan demikian, dapat disimpulkan bahwa dalam tindak pidana penggelapan unsur perbuatan menguasai harus sudah terlaksana atau selesai misalnya dengan menjual benda tersebut, digunakan sendiri dan lain-lain. Apabila penguasaan tersebut tidak bertentangan dengan sifat dari hak dengan hak mana benda itu dapat berada dibawah kekuasaannya, maka ini tidak memenuhi unsur dalam Pasal 372 KUHP. (Lamintang P. L., 2013)

Penggelapan dengan pemberatan merupakan Kejahatan yang diancam dengan hukuman yang lebih berat, bentuk-bentuk penggelapan yang di perberat diatur dalam pasal 374 dan 375 KUHP. Faktor yang menyebabkan lebih berat dari bentuk pokoknya, disandarkan pada lebih besarnya kepercayaan yang di berikan pada orang yang menguasai benda yang digelapkan.

Pasal 374 mengatakan bahwa "penggelapan yang dilakukan oleh orang yang memegang barang itu berhubung dengan pekerjaannya atau jabatannya atau karena ia mendapatkan upah, dihukum penjara selama-lamanya lima tahun"

Apabila rumusan tersebut dirinci, maka terdiri dari unsurunsur sebagai berikut:

1. Semua unsur penggelepan dalam bentuk pokok ( Pasal 372 )

2. Unsur-unsur khusus yang memberatkan yakni beradanya benda dalam kekuasaan petindak disebabkan oleh :

a. karena ada hubungan kerja.

b. karena mata pencarian.

c. karena mendapatkan upah untuk itu.

Beradanya benda di tangan seseorang yang disebabkan oleh ketiga hal di atas, adalah hubungan yang sedemikian rupa antara seseorang yang menguasai benda, menunjukan kepercayaan yang lebih besar pada orang itu. Seharusnya dengan kepercayaan yang lebih besar, ia lebih memperhatikan keselamatan dan pengurusannya bukan menyalahgunakan kepercayaan yang besar itu.

Perbedaan yang mendasar antara penggelapan dan pencurian, adalah penggelapan didasari atas rasa kepercayaan sehingga orang tersebut mau memeberikan harta bendanya tanpa 
ada paksaan. Sedangkan, pencurian adalah mengambil atau menguasai secara tidak sah harta milik orang lain tanpa seizin pemilik. Jika dibandingkan dengan tindak pidana pencurian, tindak pidana penggelapan merupakan suatu jenis tindak pidana yang baru didalam hukum jerman lama, dan membuat perbedaan yang disebut pencurian yang dikenal dengan menguasai secara tidak sah. (Lamintang P. L., 2013)

Unsur-unsur yang memberatkan itu adalah :

\section{Hubungan Kerja}

Hubungan kerja ini merupakan hubungan pelaku sebagai bawahan terhadap atasannya didalam lingkungan pekerjaannya, secara konkret hubungan antara karyawan swasta dengan majikannya, dalam kasus yang penulis analisis, Muhamad Zaki memang sudah tidak menjadi karyawan tetapi pelaku Muhamad Zaki masih menggunakan hubungan kerja dengan tempat pelaku bekerja dan beberapa orang yang masih menjadi karyawan di PT. Holcim Indonesia sewaktu masih bekerja untuk melakukan penggelapan. Hal ini dapat pelaku lakukan karena beberapa pekerja di PT. Holcim Indonesia tidak mengetahui jika pelaku sudah tidak bekerja dan dengan memanfaatkan orang lain untuk mengklaim atau mencairkan dana. Dalam hal ini pelaku masih dapat menggunakan hubungan kerjanya untuk melakukan tindak Pidana penggelapan.

\section{Mata Pencaharian/ Jabatan (beroep)}

Selain diterjemahkan dengan mata pencaharian, beroep juga diterjemahkan karena jabatan atau dengan pekerjaan. Dalam hal ini maka terdakwa melakukan penggelapan dikarenakan jabatannya di dalam pekerjaan atau mata pencahariannya. Seorang bendahara yang merupakan pengurus keuangan dari suatu perusahaan mempunyai hubungan menguasai antar dia dengan uang yang diurus dan menjadi tanggung jawabnya dikarenakan jabatan yang dimilikinya. Namun apabila menyalahgunakan uang yang menjadi tanggung jawab dan berada dalam pengurusannya itu, misalnya digunakan untuk keperluan sehari-hari maka telah terjadi penggelapan. Dalam hal ini pelaku Muhamda Zaki pernah memiliki jabatan sebagai Corporate License dengan tugas mengurus perijinan seperti IMB, ijin domisili, UUG, TDUP, Ijin alat-alat berat dengan 
sengaja melakukan tindak Pidana penggelapan dana perusahaan dalam penguasaannya untuk keperluan pribadinya memang bukan menyalahgunakan dana atas tanggung jawab dalam jabatannya, tetapi ia menyalahgunakan rembusment yang kemudian dicairkan selama pelaku bekerja di PT. Holcim Indonesia dengan melakukan pemalsuan identitas secara berulang.

3. Mendapat Upah Khusus

Maksud dari mendapat upah khusus adalah bahwa seseorang mendapat upah tertentu berhubung dengan ia mendapatkan suatu kepercayaan karena suatu perjanjian oleh sebab diserahi sesuatu benda. Sebagai contoh seorang pekerja stasiun membawakan barang orang penumpang dengan upah uang, akan tetapi barang tersebut digelapkan oleh pekerja tersebut hal ini termasuk dalam penggelapan dengan pemberatan dikarenakan barang yang digelapkan tadi berada dalam kekuasaannya bukan karena kejahatan.

Pertimbangan hakim dalam mengkualifikasi unsur-unsur tindak pidana penggelapan dengan jabatan sebagaimana pada putusan Nomor 1316/Pid.B/2016/Pn.Jkt.Sel berdasarkan pasal 374 KUHP

Terdakwa didakwa oleh Penuntut Umum dengan dakwaan kesatu yaitu Pasal 374 KUHP dakwaan kedua yaitu Pasal 378 KUHP dan dakwaan ketiga yaitu Pasal 372 KUHP. Berdasarkan dakwaan alternatif tersebut, maka Majelis Hakim akan memilih dakwaan yang berpotensi terpenuhinya diantara dakwaan kesatu dan dakwaan kedua berdasarkan fakta-fakta hukum yang terungkap dipersidangan dan berdasarkan penilaian Majelis Hakim bahwa dakwaan kedua memiliki potensi dan sesuai dengan fakta persidangan sehingga dakwaan pertama dan ketiga tidak perlu lagi dipertimbangkan sehingga Terdakwa dinyatakan secara sah dan bersalah melakukan tindak pidana penipuan dengan Pasal 378 KUHP dengan pertimbangan sebagai berikut:

Ad.1. Barang siapa

Bahwa yang dimaksud dengan "barang siapa" adalah setiap orang atau siapa saja yang menjadi subjek hukum yang dalam keadaan sehat jasmani dan rohaninya, yang dapat dipertanggung jawabkan atas perbuatannya. 
Bahwa dalam perkara ini telah diajukan ke persidangan seorang Terdakwa bernama Muhamad Zaki yang didakwa telah melakukan tindak pidana dan Terdakwa tersebut telah membenarkan identitas dirinya sebagaimana termuat dalam dakwaan Penuntut Umum, maka orang yang dimaksud dalam perkara ini adalah benar ditujukan kepada Terdakwa tersebut di atas, sehingga tidak salah orang (error in persona);

Bahwa berdasarkan pertimbangan tersebut di atas, Majelis Hakim berpendapat unsur "barang siapa" telah terpenuhi;

Ad.2. Dengan maksud menguntungkan diri sendiri atau orang lain secara melawan hukum.

Yang dimaksud dengan unsur dengan maksud untuk menguntungkan diri sendiri atau orang lain secara melawan hukum adalah unsur kesalahan dengan tegas ditentukan adanya kesengajaan dari si pelaku, oleh sebab itu ditempatkan pada awal perumusan, artinya semua unsur-unsur berikutnya dipengaruhinya. Dengan demikian si pelaku Muhammad Zaki menyadari bahwa ia secara melawan hukum bermaksud untuk menguntungkan dirinya sendiri atau orang lain.

Ad.3. Dengan memakai nama palsu atau martabat palsu, dengan tipu muslihat atau rangkaian kebohongan menggerakkan orang lain untuk menyerahkan barang sesuatu kepadanya atau supaya memberi utang maupun menghapuskan piutang.

Berdasarkan fakta-fakta yang terungkap dipersidangan, yang diperoleh dari keterangan saksi-saksi, barang bukti serta keterangan terdakwa terungkap fakta-fakta hukum bahwa awalnya terdakwa MUHAMAD ZAKI pernah bekerja di Kantor PT. HOLCIM INDONESIA yang beralamat di Gd. Talavera Jalan TB. Simatupang Cilandak Jakarta Selatan dan jabatan terkhir terdakwa yaitu Corporate License PT. Holcim Indonesia bertugas mengurus perijinan batching plan PT. Holcim Indonesia, seperti IMB, Ijin Domisili, UUG, TDUP, Ijin Lingkungan, Ijin Alat-alat berat di wilayah Jabodetabek dan Jawa Barat dan terdakwa berhenti bekerja sejak tanggal 7 September 2016, pada pertengahan tahun 2016 terdakwa yang saat itu masih bekerja dan menjabat sebagai Corporate License PT. Holcim Indonesia, mengetahui adanya kelemahan perusahaan terkait pencairan Klaim Medical di kasir kantor PT. Holcim Indonesia yang prosedurnya antara lain sebagai berikut awalnya karyawan mengirimkan bukti biaya berobat atau Apotik ke Klinik Perusahaan Holcim yang berada di Pabrik Narogong Gunung Putri Bogor. Kemudian oleh Klinik diperiksa, 
apakah bisa di Claim Reimbursement atau tidak. Bila bisa, klinik akan menerbitkan Slip Pengambilan Uang Penggantian Biaya Pengobatan dan dikirimkan kembali kepada karyawan yang bersangkutan di Gd. Talavera.

Berdasarkan unsur-unsur, fakta dan kronologi bahwa Tindak Pidana yang dilakukan oleh terdakwa yang saat itu masih aktif sebagai pekerja mempunyai kewenangan dan mendapat upah maka Penulis mengenalisis bahwa perbuatan terdakwa Muhammad Zaki termasuk tindak pidana penggelapan dengan menggunakan jabatan.

Penerapan sanksi pidana terhadap pelaku dalam Putusan Nomor 1316/Pid.B/2017/PN.Jkt.Sel berdasarkan teori pemidanaan

Pidana yang dijatuhkan hakim kepada terdakwa adalah keputusan yang berdasarkan hukum telah melalui proses hukum acara. Hakim mempunyai kebebasan mandiri mempertimbangkan hukum dalam mengkualifikasi tindak pidana penggelapan terhadap putusan yang ditanganinya. Tidak hanya hukum acara yang menjadi dasar pertimbangan hakim dalam memutuskan perkara, teori-teori pertanggungjawaban serta tujuan pertanggungjawaban pidana juga bagian dari dasar pertimbangan hakim.

Dalam hukum pidana terhadap seseoraang yang melakukan pelanggaran atau suatu perbuatan tindak pidana maka dalam pertanggungjawaban diperlukan asas-asas hukum pidana. Salah satu asas hukum pidana adalah asas hukum nullum delictum nulla poena sine pravia lege atau yang sering disebut dengan asas legalitass, asas ini menjadi dasar pokok yang tidak tertulis dalam menjatuhi pidana pada orang yang telah melakukan perbuatan pidana "tidak dipidana jika tidak ada kesalahan". Dasar ini adalah mengenai dipertanggungjawabkannya seseorang atas perbuatan yang telah dilakukannya. Artinya seseorang baru dapat diminta pertanggunngjawabannya apabila seseorang tersebut melakukan kesalahan atau melakukan perbuatan yang melanggar peraturan perundang-undangan. Asas legalitas ini mengandung pengertian, tidak ada perbuatan yang dilarang dan diancam dengan pidana kalau hal itu terlebih dahulu belum dinyatakan dalam suatu aturan perundangundangan. Maksud dari hal tersebut adalah seseorang baru dapat dimintakan pertanggungjawabn apabila perbuatan itu memang telah diatur, tidak dapat seseorang dihukum atau dimintakan pertanggungjawabannya apabila peraturan tersebut muncul setelah adanya perbuatan pidana. Untuk menentukan adanya perbuatan 
pidana tidak boleh menggunakan kata kias, serta aturan-aturan hukum pidana tersebut tidak berlaku surut. (Hanafi Amrani, 2015)

Selanjutnya Chairul Huda berpendapat bahwa pertanggungjawaban pidana merupakan Dasar adanya tindak pidana adalah asas legalitas, sedangkan dapat dipidananya pembuat adalah atas dasar kesalahan, hal ini berarti bahwa seseorang akan mempunya pertanggungjawaban pidana bila ia telah melakukan perbuatan yang salah dan bertentangan dengan hukum. Pada hakikatnya pertanggungjawaban pidana adalah suatu bentuk mekanisme yang diciptakan untuk berekasi atas pelanggaran suatu perbuatan tertentu yang telah disepakati. (Huda, 2006) Menurut Roeslan Saleh mengatakan teori pertanggungjawaban pidana, yaitu sebagai berikut: Tanggung jawab pidana dapat diartikan sebagai akibat lebih lanjut yang harus ditanggung oleh siapa saja yang telah bersikap tindak, baik yang selaras dengan hukum atau yang bertentangan dengan hukum. Tanggung jawab pidana adalah akibat lebih lanjut yang harus diterima, dibayar atau ditanggung seseorang yang melakukan tindak pidana secara langsung dan tidak langsung. (Saleh, 1990)

Dalam pertanggungjawaban pidana maka beban pertanggungjawaban dibebankan kepada pelaku pelanggaran tindak pidana berkaitan dengan dasar untuk menjatuhkan sanksi pidana. Seseorang akan memiliki sifat pertanggungjawaban pidana apabila suatu hal atau perbuatan yang dilakukan olehnya bersifat melawan hukum, namun seseorang dapat hilang sifat bertanggungjawabnya apabila didalam dirinya ditemukan suatu unsur yang menyebabkan hilangnya kemampuan bertanggungjawab seseorang.

Seperti yang telah diutarakan sebelumnya mengenai pertanggungjawaban pidana bahwa seseorang tidak dapat dijatuhi pidana bila tidak melanggar perbuatan pidana. Hal ini berarti bahwa pertanggungjawaban pidana hanya dapat terjadi jika sebelumnya seseorang telah melakukan tindak pidana. Moeljatno mengatakan bahwa orang tidak mungkin dipertanggungjawabakan (dijatuhi pidana) kalau dia tidak melakukan perbuatan pidana. Tindak pidana itu sendiri terdiri dari dua unsur, yaitu unsur objektif dimana unsur ini pada umumnya dapat terdiri atas suatu perbuatan ataupun suatu akibat dan unsur subjektif yang terdiri atas suatu kehendak atau tujuan, yang terdapat dalam jiwa pelaku, unsur dirumuskan dengan istilah sengaja, niat dan maksud. Oleh karena itu seseorang baru dapat dijatuhi pidana bila unsur subjektif ataupun unsur objektif di dalam pasal yang dikenakan terpenuhi. 
Menurut pendapat penulis dalam hal ini terdakwa Muhammad Zaki mampu bertanggungjawab karena dari perbuatan terdakwa. Kemudian terdakwa melawan hukum artinya unsur mutlak dari tiaptiap perbuatan pidana yang telah dilakukan terdakwa. Kemampuan bertanggungjawab terdakwa sudah cukup dewasa dapat membedakan antara perbuatan yang baik dan yang buruk dan dalam keadaan sehat dan tidak mengalami gangguan jiwa. Dari aspek pertanggungjawaban pidana diatas terdakwa memenuhi unsur-unsurnya, sehingga layak di pertanggung jawabkan perbuatannya.

Berdasarkan uraian, maka dalam hal pertanggungjawaban pidana terdakwa yang telah mengakibatkan kerugian terhadap PT. Holcim Indonesia. Hal ini dapat dilihat dari alat bukti, keterangan saksi dan barang bukti berupa slip dan copy bukti transaksi tunai. Berdasarkan pemeriksaan didalam persidangan tidak terungkap adanya alasan pembenar dan pemaaf berdasarkan yang ditentukan Undang-Undang. Maka terdakwa harus dijatuhi hukuman pidana berdasarkan kesalahannya sesuai dengan pertimbangan hakim dalam memberi amar putusan.

\section{KESIMPULAN}

Pertama, Dalam putusan Pengadilan Negeri Jakarta Selatan Nomor 1316/Pid.B/2017/Pn.Jkt.Sel hakim menyatakan bahwa Terdakwa secara sah telah melakukan tindak pidana penipuan dan dikenakan Pasal 378 KUHP. Dalam persidangan terbukti terdakwa memang benar telah berniat untuk menguntungkan diri sendiri, Dengan memakai nama palsu, martabat palsu atau sifat palsu, tipu muslihat atau rangkaian kebohongan. Berdasarkan unsur-unsur Tindak Pidana yang dilakukan oleh terdakwa yang saat itu masih aktif sebagai pekerja mempunyai kewenangan dan mendapat upah maka Penulis menyimpulkan bahwa perbuatan terdakwa Muhammad Zaki termasuk tindak pidana penggelapan.

Kedua, Dalam teori pemidanaan kesalahan yang mengakibatkan dipidananya terdakwa maka terdakwa haruslah melakukan perbuatan pidana, mampu bertanggung jawab dengan kesengajaan atau kealpaan dan tidak adanya alasan pemaaf. Pada kronologi dalam Putusan Pengadilan Negeri Jakarta Selatan Nomor 1316/Pid.B/2017/Pn.Jkt.Sel dan juga dalam bab pembahasan jelas bahwa terdakwa Muhammad Zaki memenuhi syarat sah untuk dijatuhkan pidana. 


\section{SARAN}

Pertama, Hakim dalam menjatuhkan pidana terhadap pelaku dan orang yang turut serta dalam tindak pidana penipuan disarankan untuk mempertimbangkan berbagai aspek yang menyebabkan terjadinya tindak pidana, kepentingan masyarakat terhadap pemberantasan tindak pidana terhadap orang yang turut serta dalam tindak pidana penipuan. Hal ini penting dilaksanakan agar sanksi pidana yang diberikan kepada terdakwa dan yang turut serta benarbenar adil sesuai hukum yang berlaku.

Kedua, Dalam prosedur pencairan Claim Medical atau pengganti biaya uang obat di PT. Holcim Indonesia seharusnya pihak perusahaan selalu mengkonfirmasi kepada klinik perusahaan setiap adanya penerbitan Claim guna memastikan keb enarandan keaslian dari slip tersebut.

\section{DAFTAR PUSTAKA}

\section{Buku}

Andi Hamzah, 1997, Asas-Asas Hukum Pidana, Jakarta : Rineka Cipta.

Andi Zainal Abidin, 1987, Asas-Asas Hukum Pidana Bagian Pertama, Bandung : Alumni.

Harapan, A. D. (2017). HUKUM DAN TEKLOGI SUATU KAJIAN TEORITIS TERHADAP PENOMENA LAYANAN TRANSFORTASI ONLINE. Jurnal Surya Kencana Satu: Dinamika Masalah Hukum dan Keadilan, 6(1), 20-39.

C.S.T. Kansil, Christine, 2000, Kamus Istilah Aneka Hukum, Jakarta : Pustaka Harapan.

Chairul Huda, 2006, Dari Tindak Pidana Tanpa Kesalahan Menuju Kepada Tiada Pertanggung jawab Pidana Tanpa Kesalahan, Cetakan ke-2, Jakarta : Kencana

Hanafi Amrani, Mahrus Ali, 2015, Sistem Pertanggungjawaban Pidana, Jakarta : Rajawali Pers.

Laden Marpaung, 2005, Asas Teori Praktek Hukum Pidana, Jakarta : Sinar Grafika.

M.Sudrajat Bassar, 1984, Tindak-Tindak Pidana Tertentu dalam KUHP, Bandung : Remaja Karya

Moeljatno, 2008, Asas-Asas Hukum Pidana, Jakarta : Rieneka Cipta.

P.A.F. Lamintang, dan Theo Lamintang, 2013, Kejahatan Terhadap Harta Kekayaan, cetakan ke-2, Bandung: Sinar Grafika. 
P.A.F Lamintang, 1999, Dasar-Dasar Hukum Pidana Indonesia, Bandung : PT. Cipta aditya bakti. , 1984, KUHAP Dengan Pembahasan Secara Yuridis Menurut Yurisprudensi Dan Ilmu Pengetahuan Hukum Pidana, Bandung : Sinar Baru.

Roeslan Saleh, 1990, Perbuatan Pidana dan Pertanggungjawaban Pidana, Jakarta : Aksara Baru.

Soemitro, 1998, Metodologi Penelitian Hukum dan Jurimetri, Jakarta Ghalia Indonesia.

Tongat, 2006, Hukum Pidana Materiil, Malang : UMM Press.

Wibowo, F. S., Damanik, D., Harapan, A. D., \& Nurhidayati, H. (2015). PEMBERDAYAAN MASYARAKAT DALAM AGROWISATA BELIMBING DEWA DI KELURAHAN PASIR PUTIH DEPOK. Tourism Scientific Journal, 1(1), 61-84. 